Citation: G. Pappalardo, G. Chinnici, R. Selvaggi, B. Pecorino (2020) Assessing the Effects of the Environment on Consumers' Evaluations for Wine. Wine Economics and Policy 9(1): 31-42. doi: 10.36253/web-7851

Copyright: (c) 2020 G. Pappalardo, G. Chinnici, R. Selvaggi, B. Pecorino. This is an open access, peer-reviewed article published by Firenze University Press (http://www.fupress.com/wep) and distributed under the terms of the Creative Commons Attribution License, which permits unrestricted use, distribution, and reproduction in any medium, provided the original author and source are credited.

Data Availability Statement: All relevant data are within the paper and its Supporting Information files.

Competing Interests: The Author(s) declare(s) no conflict of interest.
Original Research Article

\section{Assessing the Effects of the Environment on Consumers' Evaluations for Wine}

\author{
Gioacchino Pappalardo, Gaetano Chinnici*, Roberta Selvaggi, Biagio \\ PECORINO \\ Department of Agriculture, Food and Environment (Di3A), University of Catania, Via \\ Santa Sofia 98-100, 95123 Catania, Italy. ${ }^{*}$ Corresponding author \\ E-mail: gioacchino.pappalardo@unict.it,chinnici@unict.it, roberta.selvaggi@unict.it, \\ pecorino@unict.it
}

\begin{abstract}
In the wine sector, experiential marketing is becoming increasingly important since the success of a wine hinges on "experiential" attributes that include hedonic and symbolic values associated with emotions. An aspect not yet fully explored in the scientific literature concerns the extent to which emotions aroused by the environment where wine is consumed are able to influence consumers' evaluation of wine. To this end, we conducted an economic experiment in Italy in the territory of Mt Etna, Sicily and through a non-hypothetical experimental auction we assessed the effects of 10 emotions related to the environment of Mt Etna on consumers' Willingness to Pay (WTP) for Etna wine. The results of this study show that the values of consumers' WTP for wine are affected by emotions aroused by the experiential environment of Mt Etna.
\end{abstract}

Keywords: wine, experiential consumption, experimental auction.

\section{INTRODUCTION AND PURPOSE OF THE STUDY}

Recently, companies operating in the agro-food industry have adopted business models related to environmental, economic and social sustainability (Schimmenti et al., 2016; Galati et al., 2019a). The wine industry has implemented initiatives aimed at both sustainability and changes in consumer behaviour, as purchasing decisions are increasingly influenced by environmental and social aspects, and at identifying web-marketing behavioural models (Galati et al., 2017; Iaia et al., 2017; Capitello et al., 2019). Consumers' willingness to pay for wine has increased for products that offer greater sustainability guarantees (Di Vita et al., 2019; Galati et al., 2019a).

Until recently, scientific literature has focused its attention on the main factors influencing the behaviour of wine consumers. Reference literature is quite extensive and has focused on the consumer's willingness to pay more for wines with particular characteristics of healthiness and environmental sustainability. Consumer interest in both the quality and healthiness of the wines as well as the social and environmental impact of their consumption, has given rise to increased attention to the information displayed on the label 
as a tool to reduce the risk associated with wine purchasing (Galati et al., 2019b).

In this context, marketing strategies used in the wine sector by businesses are diversified by selling experiences, feelings and values that involve consumers on a personal level (Goode et al, 2010; Santini et al, 2013). From the perspective of 'experiential marketing' (Pine and Gilmore, 1999; Schmitt, 2010), these new strategies aim to satisfy a new demand from wine consumers towards intangible services related to tradition and the environment where the wine is produced and consumed (Pomarici et al, 2017). In the wine sector, experiential marketing is becoming increasingly important since the success of a wine hinges on 'experiential' features that include the hedonistic and symbolic values associated with emotions (Santini et al, 2011; Alebaki et al., 2015).

Emotions play an important role in many aspects of food consumption and have been widely analysed in scientific literature (Kotler, 1973; Mehrabian and Russell, 1974). Emotions, broadly defined as a complex state of feelings that translate into physical and psychological changes that can influence thinking and behavior (Spinelli, 2017), are important for marketing organizations as they help them understand consumer behaviour and have some control over post-purchase behaviour. In the wine sector, an interesting aspect regards the effects of emotions related to the environment wine is consumed in as evaluated by consumers. These 'environmental' emotions are important factors when experiential marketing is put into practice and can be expected to influence consumers' decision-making (Platania et al., 2016a). Stimuli from the place of consumption can influence the sensory and psychological markers associated with wine consumption (Orth and Bourrain, 2005). The characteristics of wine destinations also affect consumers' intentions to revisit wine regions (Bonn et al., 2016). Motivations as a basis for segmenting tourism markets have provided information on why consumers desire to visit wine destinations and regions (Bruwer et al., 2018).

One aspect that has not been fully explored yet in scientific literature concerns the extent to which the emotions aroused by the environment where wine is consumed are able to influence consumers' evaluation of it. To our knowledge, no study has examined whether the emotional state aroused by the environment consumers evaluate food in persists after the consumer has experienced visiting a place capable of arousing such emotions. This is an important topic for both companies and marketers since marketing practices related to the environment can lead to an increase in consumer demand for wine. For this purpose, in this study we assess whether the emotions related to the environment wine is consumed in affects consumers' WTP for wine.

In the wine sector, previous studies have shown that the environment wine consumed in can stimulate behavioural responses among consumers that can lead to wine purchases (Platania et al., 2016a, Sturiale and Scuderi, 2017). Environmental attributes that influence the consumption of wine can be related to the place of consumption (Orth and Bourrain, 2005; Platania et al., 2016b), region of origin (Lange et al., 2002; Alant and Bruwer, 2004; Yuan et al., 2005; Vecchio, 2013) and cultural attractions of the production site which are capable of developing emotions in highly motivated consumers who come from places far from the production area (Getz and Brown, 2006). Understanding how the environment affects wine evaluation and consumption remains an unresolved issue. Specifically, one interesting issue that has not been fully explored yet which we analysed in our study relates to the emotions aroused by attractive environments (Voss et al., 2008; Candi et al., 2013; Creusen et al., 2018) which can enhance the hedonic and symbolic value of a product (Chitturi et al., 2008; Teng et al., 2007; Reimann et al., 2010; Candi et al., 2017).

With the purpose of observing whether the emotions related to attractive environments affect consumers' wine evaluation, we conducted a non-hypothetical experimental auction in Italy to estimate the experiential effects of the emotions on consumers' WTP for wine. The experiment involved recruiting people to blindly evaluate three types of wine in conditions of emotions aroused by the environment of Mt. Etna in Sicily, the largest volcano in Europe and one of the most wellknown wine areas in Italy.

\section{BACKGROUND TO MT ETNA}

The environment of the volcano can arouse a wide range of emotions in visitors mostly because the semilunar like landscape creates attraction mixed with fear. Numerous studies have proven the existence of emotions aroused by potentially hostile yet at the same time attractive environments such as volcanoes (Zube et al, 1975; Kaplan, 1987; Purcell et al, 2001; Böhm, 2003; Bird et al. 2011; Ruiz and Hernández, 2014).

Etna is Europe's largest volcano attracting millions of visitors from all over the world every year. Furthermore, in June 2013, Etna was inscribed in UNESCO's World Heritage List.

Over the course of centuries, a rich agriculture has developed around the volcano mostly made up of fruit, 
Table 1. Experimental treatments.

\begin{tabular}{|c|c|c|c|c|c|c|}
\hline Design & Groups & $\begin{array}{c}\text { Treatment } \\
\text { denomination }\end{array}$ & $\begin{array}{l}\text { Experiential } \\
\text { consumption }\end{array}$ & $\begin{array}{l}\text { Location of } \\
\text { treatment }\end{array}$ & Wine tasting & $\begin{array}{l}\text { Rounds in the } \\
\text { auction }\end{array}$ \\
\hline \multirow[t]{2}{*}{ Pre-test } & Control group & TC1 & $\mathrm{NO}$ & Sensory lab & Blind & 5 \\
\hline & Treated group & TT1 & $\mathrm{NO}$ & Sensory lab & Blind & 5 \\
\hline \multirow[t]{2}{*}{ Post-test } & Control group & TC2 & NO & Sensory lab & Blind & 5 \\
\hline & Treated group & TT2 & YES & Winery & Blind & 5 \\
\hline \multirow[t]{2}{*}{ Follow-up test } & Control group & TC3 & NO & Sensory lab & Blind & 5 \\
\hline & Treated group & TT3 & $\mathrm{NO}$ & Sensory lab & Blind & 5 \\
\hline
\end{tabular}

olive and vine production. Most of these crops can boast of EU recognition as 'Protected Designation of Origin' (PDO). Man's presence has left a profound imprint on Etna's agricultural landscape through the building of terracettes, barns, mill, wineries and other architectural structures.

As a consequence, Mount Etna is a force of nature potentially capable of augmenting the experiential component of the environment and context consumers evaluate food products in and in particular wine.

\section{METHODOLOGY}

\subsection{Experimental design}

To evaluate the effects of the emotions on consumers' evaluation of wine, we conducted an economic experiment in the Mt. Etna area (Italy). A sample of 140 students participated in a non-hypothetical experimental auction which is a well-established method of assessing the WTP for food products (Lusk and Shogren, 2007; Pappalardo and Lusk, 2016; Wongprawmas et al. 2016; Pappalardo et al. 2017; Pappalardo et al., 2018; Selvaggi et al., 2018a and 20181b). This type of experiment offers the advantage of providing an incentive for participants to truly reveal their preferences. Indeed, an experimental auction simulates a real market where consumers can make the decision to buy or not to buy a product through a real money transaction providing researchers with an accurate estimate of product values (Lusk and Shogren, 2007). Moreover, each participant will be provided with a gadget at the end of the auction protocol.

Few studies have used non-hypothetical methods to estimate the effects of intangible factors in consumers' WTP for wine (Bradley et al., 2015). In this study, we used the random $n t h$ price auction method (Shogren et al., 2001; List, 2003) since this method is incentive-compatible and widely used in many empirical evaluation studies (Huffman et al., 2003; Capra et al., 2010; Chern et al., 2013). Participants do not know the winning position until all the bids have been submitted, thus removing the competitive biases that might exist in other experimental auction mechanisms, such as the secondprice auction (Shogren et al., 2001).

The novelty of this paper is combining a non-hypothetical evaluation method with an evaluation of emotions to identify a consumer's WTP for wine.

In the first step of the study, we recruited people for the experimental auction, and at the same time, people were asked questions on the emotions aroused by $\mathrm{Mt}$ Etna. We conducted our experiment in Sicily, Italy, in May 2017. A total of 140 people were recruited from a pool of students attending the 3rd year of the Degree in Food Science and Technology at the University of Catania (Italy). Students were recruited by using a recruitment questionnaire in which they declared to be wine consumers and to have the minimum age (18 years old) required by the Italian legislation authorizing the consumption of alcohol (Law 30 March 2001 No. 125 "Framework Law on alcohol and related problems").

In the second step of the study, WTP for wine was elicited through a non-hypothetical nth price auction method. Participants were randomly assigned to two groups: 'control' and 'treated' (Table 1). Each participant in the control group took part in three treatments called Treatment Control 1 (TC1), Treatment Control 2 (TC2), and Treatment Control 3 (TC3). Similarly, each participant in the treated group took part in three treatments called Treatment Treated 1 (TT1), Treatment Treated 2 (TT2), and Treatment Treated 3 (TT3). The three treatments within each group (six treatments in total) were carried out at intervals of one week during May 2017².

\footnotetext{
${ }^{1}$ Unfortunately, it was not possible at the end of the experiment to have equal numbers in the control and treated groups. Of the 140 participants initially recruited and who participated in the first treatment $(70$ in the treatment TC1 and 70 in the treatment TT1), only 118 (66 in the control group and 52 in the treated group) participated in all three treatments. The study only considered data concerning the participants in all three treatments.
} 
The three treatments for the participants in the control group (TC1, TC2, and TC3) were carried out in a sensory lab, while participants in the treated group received the first treatment (TT1) in the sensory lab, the second treatment (TT2) in a winery on Mt. Etna, and the third treatment (TT3) in the same sensory lab. Finally, we implemented a mixed design divided into three phases: 'pre-test', 'post-test' and 'follow-up test' where the repeated criterion within the two groups was the WTP for one 0.75litre bottle of wine. In our experiment, the experiential environment was represented by a winery located on Mt. Etna.

Participants were informed in advance that they would take part in three treatments as part of an economic experiment using experimental auctions. Participants in the control group were informed that they would undergo all three treatments in a sensory lab. Those participants in the treated group were informed that they would undergo the first and third treatments in the sensory lab, while the second treatment would be held at a winery located on Mt. Etna.

More specifically, participants in the treated group carried out the second treatment (TT2) in a winery on Etna which produces Etna PDO (Protected Designation of Origin) wine. As soon as the participants arrived at the winery and before the auction started, they were invited to take a guided tour of the winery. The guided tour not only allowed participants to observe the premises of the winery but also to appreciate the architectural, and emotional journey catalysed by the majesty and elegance of the winery as well as by the links between it and Mt. Etna. After the 90-minute tour, participants were taken to the elegant premises of the barrel cellar where the experimental auction took place.

Participants were also informed that before the experimental auctions both in the sensory lab and in the winery, they would taste three types of red Etna wine. The wines used in our survey were 1) Etna Rosso "Femina" PDO, 2) Etna Rosso "Sensi" PDO, and 3) Etna Rosso "Vulcano" PDO, and they were produced by the winery that students toured. The wines were similar in terms of organoleptic characteristics and production year but were only distinguishable nominally as 'A', 'B' and ' $\mathrm{C}$ '. We used blind tastings to ensure impartiality and to avoid product-related experiential effects, that is, potential bias effects in participants' judgments due to product-related attributes. Three types of Etna wine were used to test the consistency of the results across different types of wine in the region. Participants were not informed that the wines they tasted originated from Mt. Etna.

\subsection{List of emotions}

The survey investigated whether the emotional factors related to Mt Etna affected consumers' willingness to pay (WTP) for wine. By reviewing past literature (Böhm, 2003; Bird et al. 2011; Ruiz and Hernández, 2014), 10 emotions related to volcano environments were identified (Table 2) and for each emotion the participants in our survey were asked to classify them on a scale of 1 to 5 , where 1 is equivalent to 'no important' and 5 'very important'.

Participants were asked to evaluate their emotional reactions immediately after each treatment to assess WTP.

\subsection{Auction procedure}

In all the treatments, the participants took part in a random $n$th price auction with five rounds of bidding in each treatment according to the procedure described below.

Step 1: Upon arrival at the venue, after signing the consent form, each bidder received an ID and was invited to sit in a specific seat. We then proceeded to blind tasting a $30 \mathrm{ml}$ sample of each of the three wines.

Step 2: At the end of the tasting, the coordinator clearly explained in detail the random nth price auction mechanism to participants.

Step 3: To ensure participants understood how the auction mechanism worked, we conducted a practice

Table 2. List of emotions aroused when visiting or thinking about Mt Etna.

\begin{tabular}{|c|c|}
\hline Emotions & Meaning \\
\hline Tranquil & $\begin{array}{l}\text { The state of being calm and peaceful without noise, } \\
\text { violence, worry, etc. }\end{array}$ \\
\hline Ecstatic & $\begin{array}{l}\text { A state of being extremely happy and feeling or } \\
\text { showing ecstasy. }\end{array}$ \\
\hline Inner peace & $\begin{array}{l}\text { A state of being mentally and spiritually at peace. } \\
\text { Being 'at peace' is to be healthy and the opposite of } \\
\text { being stressed or anxious. }\end{array}$ \\
\hline Nostalgia & $\begin{array}{l}\text { The feeling of pleasure and also slight sadness when } \\
\text { you think about things that happened in the past. }\end{array}$ \\
\hline Excited & $\begin{array}{l}\text { The state of being or feeling very happy and } \\
\text { enthusiastic. }\end{array}$ \\
\hline Frightened & The feeling or condition of being afraid. \\
\hline Fascinated & A state of being extremely interested by something. \\
\hline Enchanted & $\begin{array}{l}\text { Being affected by magic or seeming to be affected by } \\
\text { magic. }\end{array}$ \\
\hline Amazed & A state of being extremely surprised by something. \\
\hline Surprised & $\begin{array}{l}\text { The state of being or showing surprise because } \\
\text { something has happened that you did not expect. }\end{array}$ \\
\hline
\end{tabular}


session with three different $1 \mathrm{~kg}$ generic pasta packages. This auction was only a trial session to familiarize the participants with the auction mechanism, and at the end of this, nothing was bought. Since the real auction was for three wines in five bidding rounds, we conducted the trial auction with three different types of pasta and with five bidding rounds.

Step 4: After completing the trial auctions, the real wine auction began, and each participant simultaneously submitted bids for each of the three wines. The bids were for a $0.75 \mathrm{~L}$ bottle of wine 'A', 'B' or 'C'. To avoid any issues of bias or affiliation, participants did not receive any kind of feedback between rounds, such as who was the winner or if the winning bid represented the market price (Corrigan et al., 2012).

Step 5: At the end of each round, bids were collected and arranged from highest to lowest.

Step 6: At the end of the fifth bidding round, one of the three wines was randomly drawn and chosen as the bidding wine.

Step 7: The bidding round was randomly drawn, which the price for the bidding wine would be chosen from.

Step 8: The random $n$th price (market price), whose value was between 2 and $n$, where $n$ was the number of bidders in the auction's session (ranging in our survey from 7 to 8), was randomly drawn.

Step 9: The random $n$th price was announced; the bidders who submitted a bid higher than the $n$th price won the auction. Winning bidders paid the $n$th price to buy the randomly chosen bottle in the randomly chosen round.
Step 10: All bidders who had bid a price equal to or lower than the market price did not get anything.

Step 11: All participants filled out a follow-up questionnaire containing a series of questions related to emotions aroused by Mt. Etna and its demographics.

Each participant was given $€ 20.00$ at the end of all three treatments for their participation.

\section{RESULTS}

\subsection{Descriptive analysis}

Summary statistics of the participants are shown in Table 3. The average age of the subjects was 21.71 years in the control group and 22.27 years in the treated group. Most of the subjects were female. The yearly average household income ranged from $€ 20,000$ to $€ 29,999$. Most of the participants (91\%) indicated that they had already been to Mt. Etna. As shown in the $t$-test $p$-value column, no significant differences were found between the control and treated groups regarding the variables used in our analysis except for age.

Table 4 reports the average bids for the three wines across the treatments. Consumers' WTP for each wine in the treated group was higher than the WTP in the control group both in the post- and follow-up tests. On average, for wine A, subjects in TT2 were willing to pay $€ 2.98$ for this bottle of wine in the experiential environment (winery) while those in TC2 were willing to pay $€ 1.90$ in the non-experiential environment (sensory lab). These results signify the effect Mt. Etna has on consum-

Table 3. Participants' socioeconomic characteristics.

\begin{tabular}{|c|c|c|c|c|c|c|}
\hline \multirow{2}{*}{$\begin{array}{l}\text { Variables } \\
\text { Age }\end{array}$} & \multirow{2}{*}{$\begin{array}{c}\text { Categories } \\
\text { Years }\end{array}$} & \multicolumn{2}{|c|}{$\begin{array}{l}\text { Control group } \\
\text { (66 Units) }\end{array}$} & \multicolumn{2}{|c|}{$\begin{array}{l}\text { Treated group } \\
\quad(52 \text { Units })\end{array}$} & \multirow[t]{2}{*}{$p$-value } \\
\hline & & Mean & $\%$ & Mean & $\%$ & \\
\hline & & 21.71 & & 22.27 & & $0.0868^{*}$ \\
\hline \multirow[t]{2}{*}{ Gender } & - Male & & $19.7 \%$ & & $24.5 \%$ & 0.2592 \\
\hline & - Female & & $80.3 \%$ & & $75.5 \%$ & \\
\hline \multirow[t]{6}{*}{ Income } & - less than $€ 20,000$ & & $37.9 \%$ & & $32.7 \%$ & 0.2855 \\
\hline & - from $€ 20,000$ to $€ 29,999$ & & $31.8 \%$ & & $26.5 \%$ & \\
\hline & - from $€ 30,000$ to $€ 39,999$ & & $18.2 \%$ & & $16.3 \%$ & \\
\hline & - from $€ 40,000$ to 49,999 & & $4.5 \%$ & & $8.2 \%$ & \\
\hline & - from $€ 50,000$ to 59,999 & & $3.0 \%$ & & $8.2 \%$ & \\
\hline & - more than $€ 60,000$ & & $4.5 \%$ & & $8.2 \%$ & \\
\hline \multirow[t]{2}{*}{ Visits to Mt Etna } & - Yes & & $90.9 \%$ & & $91.8 \%$ & 0.7887 \\
\hline & - No & & $9.1 \%$ & & $8.2 \%$ & \\
\hline
\end{tabular}


Table 4. Mean bids of all five rounds across the treatments.

\begin{tabular}{lcccccc}
\hline \multirow{2}{*}{ Treatments } & \multicolumn{2}{c}{ Wine A } & \multicolumn{2}{c}{ Wine B } & \multicolumn{2}{c}{ Wine C } \\
\cline { 2 - 7 } & Mean & St. Dev. & Mean & St. Dev. & Mean & St. Dev. \\
\hline TC1 (pre-test) & 2.02 & 2.06 & 2.09 & 1.48 & 2.73 & 2.90 \\
TT1 (pre-test) & 1.85 & 1.54 & 2.11 & 2.02 & 2.00 & 1.69 \\
TC2 (post-test) & 1.90 & 1.74 & 1.71 & 1.54 & 1.97 & 1.97 \\
TT2 (post-test) & 2.98 & 1.78 & 2.70 & 2.11 & 2.92 & 1.76 \\
TC3 (follow-up) & 1.80 & 1.55 & 1.69 & 1.09 & 1.95 & 1.62 \\
TT3 (follow-up) & 2.38 & 1.50 & 2.53 & 1.71 & 2.85 & 1.81 \\
\hline
\end{tabular}

Sample size $=$ control group: 66 units; treated group: 52 units.

Note: TC1: Treatment Control 1; TC2: Treatment Control 2; TC3: Treatment Control 3; TT1: Treatment Treated 1; TT2: Treatment Treated 2; TT3: Treatment Treated 3.

ers' evaluation of wine. Interestingly, WTP in TT3 was higher than WTP in TT1 for all three wines, reflecting the effect of having previously visited the winery.

Referring to the emotions aroused by Mt. Etna, the mean values for each emotion at the end of each treatment are shown in Table 5 where all the emotions were valued more highly than the mean values on the scale except for 'Frightened' and 'Nostalgia'.

\subsection{Effects of the emotions on consumers' WTP for wine}

To estimate the effects of the emotions aroused by Mt. Etna on consumers' WTP for wine, we developed a regression model in which we pooled the data from all six treatments carried out by participants in the control and treated groups. A random effects regression model was then estimated with the time dimension being the total number of rounds performed by each participant in the three treatments, i.e., 15. The regression model is specified as

$B I D_{i j}=\alpha_{0}+\beta_{1}$ TDum $+\beta_{2} A_{2} \times T D u m+\beta_{3} A_{3} \times$ TDum $+\beta_{4}$ Tranquil $+\beta_{5}$ Ecstatic $+\beta_{6}$ Inner peace $+\beta_{7}$ Nostalgia $+\beta_{8}$ Excited $+\beta_{9}$ Frightened $+\beta_{10}$ Fascinated $+\beta_{11}$ Enchanted $+\beta_{12}$ Amazed $+\beta_{13}$ Surprised $+\beta_{14} X_{j}$ $+\mathrm{u}_{\mathrm{j}}+\varepsilon_{\mathrm{ij}}$

where $B I D_{i j}$ is individual $i$ 's WTP for each wine $(\mathrm{A}, \mathrm{B}$, or $\mathrm{C}$ ) in round $j$ in both the control and treated groups; $A_{2}$ is a binary variable $=1$ in treatments TC2 and TT2 and 0 otherwise; similarly, $A_{3}$ is a binary variable $=1$ in treatments TC 3 and TT3 and 0 otherwise; TDum is a binary variable $=1$ if participants belong to the treated group and 0 otherwise. Consequently, $A_{2} \times$ TDum is an interaction term between $A_{2}$ and TDum, while $A_{3}$ $\times$ TDum is an interaction term between $A_{3}$ and TDum. Tranquil, Ecstatic, Inner peace, Nostalgia, Excited, Frightened, Fascinated, Enchanted, Amazed, Surprised are the emotions aroused by Mt Etna as described in Table 2. $\mathrm{X}_{\mathrm{i}}$ denotes a vector of control variables that include general sociodemographic factors, $X_{i}$ is random effects which controls for hidden individual characteristics; and $\varepsilon_{\mathrm{ij}}$ is the i.i.d. component.

Overall, the results of the random effects model (table 6) show that participants WTP for wine is influenced by the interactive effect between treatment and membership of the Treated group $\left(A_{2} \times\right.$ TDum and $A_{3}$ $\times$ TDum), by certain emotions which change depending on the wine and by certain socio-demographics of the participants. In particular, the results show that during the second treatment (TC2 and TT2), the Treated Group participants showed a higher WTP compared to those in the Control Group.

Table 5. Summary statistics of emotions.

\begin{tabular}{|c|c|c|c|c|c|c|}
\hline \multirow[b]{2}{*}{ Emotions } & \multicolumn{3}{|c|}{ Control group } & \multicolumn{3}{|c|}{ Treated group } \\
\hline & $\begin{array}{l}\text { 1st auction } \\
\text { Mean }\end{array}$ & $\begin{array}{l}\text { 2nd auction } \\
\text { Mean }\end{array}$ & $\begin{array}{l}\text { 3rd auction } \\
\text { Mean }\end{array}$ & $\begin{array}{l}\text { 1st auction } \\
\text { Mean }\end{array}$ & $\begin{array}{l}\text { 2nd auction } \\
\text { Mean }\end{array}$ & $\begin{array}{c}\text { 3rd auction } \\
\text { Mean }\end{array}$ \\
\hline Tranquil & 3.77 & 3.77 & 3.70 & 3.69 & 3.96 & 3.81 \\
\hline Ecstatic & 3.03 & 3.27 & 3.24 & 3.31 & 3.54 & 3.69 \\
\hline Inner peace & 4.00 & 3.89 & 3.89 & 3.98 & 4.02 & 4.19 \\
\hline Nostalgia & 2.14 & 2.14 & 2.38 & 2.23 & 2.52 & 2.48 \\
\hline Excited & 3.58 & 3.65 & 3.68 & 3.79 & 3.83 & 3.88 \\
\hline Frightened & 1.83 & 2.00 & 1.92 & 1.87 & 2.02 & 1.88 \\
\hline Fascinated & 4.14 & 4.09 & 3.80 & 4.33 & 4.23 & 4.10 \\
\hline Enchanted & 3.94 & 3.91 & 3.88 & 4.10 & 4.19 & 4.15 \\
\hline Amazed & 3.58 & 3.73 & 3.59 & 3.58 & 3.71 & 3.79 \\
\hline Surprised & 3.05 & 3.32 & 3.32 & 3.25 & 3.50 & 3.65 \\
\hline
\end{tabular}


Table 6. Random effects regression results.

\begin{tabular}{|c|c|c|c|c|c|c|}
\hline \multirow{2}{*}{ Variables } & \multicolumn{2}{|c|}{ Wine A } & \multicolumn{2}{|c|}{ Wine B } & \multicolumn{2}{|c|}{ Wine $\mathrm{C}$} \\
\hline & Coefficient & $p$-value & Coefficient & $p$-value & Coefficient & $p$-value \\
\hline Treated (TDum) & -0.355 & 0.152 & -0.048 & 0.851 & -0.891 & $0.003^{* * *}$ \\
\hline Interaction $\left(\mathrm{A}_{2} \mathrm{x}\right.$ TDum $)$ & 1.316 & $0.000^{* * *}$ & 1.056 & $0.000^{* * *}$ & 1.780 & $0.000^{* * *}$ \\
\hline Interaction $\left(\mathrm{A}_{3} \mathrm{x}\right.$ TDum $)$ & 0.763 & $0.000^{* * *}$ & 0.902 & $0.000^{* * *}$ & 1.625 & $0.000^{* * *}$ \\
\hline Tranquil & -0.052 & 0.335 & -0.021 & 0.663 & 0.128 & $0.046^{\star *}$ \\
\hline Ecstatic & 0.047 & 0.320 & -0.018 & 0.681 & 0.020 & 0.725 \\
\hline Inner peace & 0.054 & 0.423 & -0.112 & $0.074^{\star}$ & 0.055 & 0.490 \\
\hline Nostalgia & -0.111 & $0.048^{\star *}$ & -0.118 & $0.024^{\star *}$ & -0.334 & $0.000^{* * *}$ \\
\hline Excited & 0.222 & $0.001^{\star * *}$ & 0.157 & $0.011^{* * *}$ & 0.249 & $0.002^{* * *}$ \\
\hline Frightened & -0.001 & 0.984 & 0.027 & 0.623 & 0.005 & 0.938 \\
\hline Fascinated & -0.061 & 0.322 & 0.099 & $0.076^{* *}$ & 0.061 & 0.393 \\
\hline Enchanted & -0.167 & $0.026^{* *}$ & -0.189 & $0.006^{* * *}$ & -0.263 & $0.003^{* * *}$ \\
\hline Amazed & -0.158 & $0.016^{* *}$ & -0.217 & $0.000^{* * *}$ & -0.170 & $0.028^{* *}$ \\
\hline Surprised & 0.159 & $0.009^{* * *}$ & 0.160 & $0.005^{* * *}$ & 0.244 & $0.001^{* * *}$ \\
\hline Gender & -0.958 & $0.000^{* * *}$ & -0.812 & 0.004 & -0.944 & $0.003^{* * *}$ \\
\hline Age & 0.090 & 0.133 & 0.016 & 0.800 & 0.067 & 0.364 \\
\hline Visits to Mt Etna & -0.213 & 0.673 & -0.636 & 0.234 & -0.205 & 0.739 \\
\hline Income & -.0520 & 0.400 & -0.014 & 0.824 & -0.062 & 0.409 \\
\hline cons & 1.531 & 0.292 & 3.603 & $0.018^{\star *}$ & 2.196 & 0.214 \\
\hline
\end{tabular}

${ }^{*},{ }^{* *}$ and ${ }^{* * *}$ denote significance at $10 \%, 5 \%$ and $1 \%$ levels, respectively.

The same result was observed during the third Treatment (TC3 and TT3). These results would seem to indicate that the experiential effect of visiting the winery during Treatment TT2 lasts over time and effects the subsequent treatment.

Table 6 also shows the parameters estimated for the emotions which influence WTP the most significant of which vary between wines and the relative coefficients showing both positive and negative signs. The positive parameters indicate there is a positive correlation between emotion and WTP. For example, with wine A, if the value of 'excited' increases by one point then WTP increases marginally by $€ 0.22$. Or with wine $C$, if the value of 'surprised' increases by one point then WTP increases by $€ 0.24$.

Instead, some statistically significant emotions have negative coefficients. For example, wine A's 'nostalgia' is negative representing a negative correlation with WTP. In marginal terms, this means that if 'nostalgia' increases by one point then WTP for wine A drops by $€ 0.11$.

Negative or positive correlations between emotions and WTP may be linked to the emotions aroused by the experiential environment used in our experiment (winery) which might have positively or negatively influenced WTP values. However, it would be better to confirm such conclusions with further research.

\section{DISCUSSION}

Our results confirm those obtained by previous research (Kotler, 1973; Orth and Bourrain, 2005; Alant and Bruwer, 2004; Yuan et al 2005; Getz and Brown, 2006; Galloway et al., 2008; Jang and Namkung, 2009; Muruganantham and Bhakat, 2013; Menini 2017) which are that experiential marketing strategies influence the willingness to pay for wine guaranteeing an increase in profits for wineries.

Nevertheless, all the previous research analysed how to identify and measure emotions in the consumption process (Richins, 1997; King and Meiselman, 2010; Kergoat et al, 2010; Prescott, 2017; Spinelli, 2017), whereas the methodological approach in this study measured the effects of emotions directly aroused by the environment of the consumption on the willingness to pay for wine. In particular, this study observed that the emotions aroused by Mt. Etna and referred to by experiential techniques can influence consumers' WTP. Specifically, these results reflect the relevant role played by environmental features not directly pertaining to the wine products. It seems remarkable that in contrast to previous studies (Creusen et al., 2018), our results suggest that the emotions aroused by the environment wine is consumed in, such as a winery recalling a high-value environment like Mt. Etna, significantly affects consumers' WTP even in 
the absence of product-related attributes such as brand or product packaging.

On this latter issue, this study highlighted a twofold aspect yet to be explored in current scientific literature. Above all, the emotions explicitly correlated to an environment with strong cultural and naturalistic ties are able to influence consumers' WTP for wine. Secondly, the emotions aroused by experiential marketing strategies which refer to places with strong cultural and naturalistic ties last over time as shown by the WTP values obtained in the follow-up test.

In particular, this study has highlighted that certain emotions aroused by Mt. Etna significantly influence consumer WTP to buy wine produced on the volcano. Those experiential marketing strategies, which refer to the Mt. Etna environment, produce an increase in WTP for the wine compared to the WTP of the same wine obtained in a non-experiential context (sensory laboratory). This is potentially important for those in the wine sector. The experiential marketing strategies, which refer directly to the emotions aroused by places with strong cultural and naturalistic ties, could provide a level of competitivity for wine sector players which others, not having such high levels of cultural and environmental factors, cannot compete with. Moreover, the competitive advantage could be amplified by effects deriving from experiential consumption which lasts over time.

\section{CONCLUSION}

This research focused on assessing the effect of emotions directly related with a high-value environment where consumers evaluate and consume wine. In our study, results suggest that emotions aroused by visiting a winery recalling the environment of Mt. Etna was positively related with wine evaluation. The results have shown that the values of consumers' WTP for wine seem to be coherent with the goal of this study regarding the effect of emotions aroused by the experiential environment of Mt Etna on consumers' WTP for wine. In fact, the WTP in the treated group was higher than that in the control group for all the wines. Moreover, the results of the random effects model showed that participants' WTP for wine is affected by different emotions aroused by Mt. Etna. The significant emotions varied between wines and the relative coefficients showed both positive and negative signs. The positive coefficients indicate that some emotions aroused by Mt Etna such as 'excited' positively affect participants' WTP for wine, and conversely some emotions such as 'nostalgia' or 'enchanted' negatively correlate with WTP.
Our findings suggest that to implement effective experiential marketing practices related to the environment, an important role is played by those 'emotions' that influence consumer buying behaviour. This aspect is potentially significant for the players involved in the wine sector such as cellar managers or wine producers since the emotions directly aroused by the environment where wine is consumed can affect consumers' WTP for wine. Ultimately, from the perspective of 'experiential marketing', the results generally suggest that emotions related to the environment could be a tool that wine producers and marketers could use to differentiate their products and increase consumer demand for their products.

Results of our survey could have relevant implications for the stakeholders involved in the wine sector. For cellar managers, experiential marketing practices explicitly related to the emotions aroused by high-value environments wine is consumed in could increase consumers' evaluation of the wine products. For wine producers, environment and related emotions can lead to an increase in wine demand that could enhance winery income. Generally, the results suggest that the environment could be a tool that wine producers and marketers could use to differentiate their products and increase consumers' demand for their products.

This study recommends that experiential marketing practices be pursued as a product differentiation tool, especially for wineries and vineyards which are located in areas with high environmental relevance. This strategy can achieve a greater acceptance from consumers and thus a competitive advantage, especially among consumers who are more aware of environmental issues. Experiential marketing strategies related to the emotions aroused by the environment wine is consumed in should not be overlooked. Therefore, the industry could exploit more effectively environmental values such as quality labels of the wine produced, compared to what has been done so far in order to enhance the organoleptic qualities and designations of the origin of the wine.

Nevertheless, it is important to remember the limitations to this study. Above all, since this study was only limited to the case of Mt. Etna, it would be necessary for future research to verify such results in other geographical contexts with strong environmental ties. Another limitation was the place of origin of the participants in the sample which was formed only by Sicilian students who are already likely to be familiar with Mt Etna and its geographical characteristics. Moreover, the study should be performed on a much wider sample of participants not just undergraduates. 
Nomenclature

\begin{tabular}{ll}
\hline Symbol & \multicolumn{1}{c}{ Description } \\
\hline EU & European Union \\
ID & Identification \\
PDO & Protected Designation of Origin \\
Random nth-price auction & Type of experimental auction \\
TC & Treatment Control \\
TT & Treatment Treated \\
UNESCO & United Nations Educational, Scientific \\
WTP & and Cultural Organization \\
\hline
\end{tabular}

\section{ACKNOWLEDGEMENTS}

A special thank goes to prof. Rodolfo M. Nayga Jr. for his support in the design of the experiment treatments and for the suggestions and support in the data analysis.

This research was conducted within the framework of the research projects "Agronomic Innovations and Economic Analysis of Biomass Production for Energy and Economic Valuation of Natural Capital" (5A722192115), financially supported by University of Catania (Italy), Project leader: Gioacchino Pappalardo.

\section{REFERENCES}

Alant, K., Bruwer, J., 2004. Wine tourism behaviour in the context of motivational framework for wine regions and cellar doors. Journal of Wine Research 15 (1), 27-37. https://doi.org/10.1080/0957126042000 300308 .

Alebaki, M., Menexes, G., Koutsouris, A., 2015. Developing a multidimensional framework for wine tourist behavior: Evidence from Greece. Wine Economics and Policy 4 (2), 98-109. https://doi.org/10.1016/j. wep.2015.11.002.

Bird, D.K., Gísladóttir, G., Dominey-Howes, D., 2011. Different communities, different perspectives: Issues affecting residents' response to a volcanic eruption in southern Iceland. Bulletin of Volcanology 73 (9), 12091227. https://doi.org/10.1007/s00445-011-0464-1.

Bonn, M.A., Cho, M., Lee, J.J., Kim, J.H. 2016. A multilevel analysis of the effects of wine destination attributes on travel constraints and revisit intention. International Journal of Contemporary Hospitality Management 28(11), 2399-2421, https://doi.org/10.1108/ IJCHM-01-2015-0010.

Böhm, G., 2003. Emotional reactions to environmental risks: Consequentialist versus ethical evaluation.
Journal of Environmental Psychology 23 (2), 199212. https://doi.org/10.1016/S0272-4944(02)00114-7.

Bradley, J.R., McCluskey, J.J., Patterson, R.W., 2015. Reputation tapping. European Review of Agricultural Economics 42 (4), 675-701. https://doi.org/10.1093/erae/ jbv003.

Bruwer, J., Prayag, G., Disegna, M. 2018. Why wine tourists visit cellar doors: Segmenting motivation and destination image. International Journal of Tourism Research 20(3), 355-366, https://doi.org/10.1002/ jtr.2187.

Candi, M., Beltagui, A., Riedel, J.C., 2013. Innovation through experience staging: motives and outcomes. Journal of Product Innovation Management 30, 279-297. https://doi.org/10.1111/j.15405885.2012.00999.x.

Candi, M., Jae, H., Makarem, S., Mohan, M., 2017. Consumer responses to functional, aesthetic, and symbolic product design in online reviews. Journal of Business Research 81, 31-39. https://doi.org/10.1016/j. jbusres.2017.08.006.

Capitello, R., Agnoli, L., Begalli, D., Codurri, S. 2014. Social media strategies and corporate brand visibility in the wine industry: Lessons from an Italian case study. EuroMed Journal of Business 9(2), 129-148, https://doi.org/10.1108/EMJB-10-2013-0046.

Capra, C.M., Lanier, K.F., Meer, S., 2010. The effects of induced mood on bidding in random nth-price auctions. Journal of Economic Behavior \& Organization 75 (2), 223-234. https://doi.org/10.1016/j. jebo.2010.04.002.

Chern, W.S., Hong, J.P., Liu, K.E., 2013. Comparison of the Vickrey Second Price and Random nth Price Auctions for Analyzing Country of Origin Labeling in Taiwan. Academia Economic Papers 41 (2), 215254.

Chitturi, R., Raghunathan, R., Mahajan, V., 2007. Form versus function: how the intensities of specific emotions evoked in functional versus hedonic trade-offs mediate product preferences. Journal of Marketing Research 44, 702-714. https://doi.org/10.1509/ jmkr.44.4.702.

Corrigan, J.R., Drichoutis, A., Lusk, J., Nayga Jr, R.M., Rousu, M., 2012. Repeated Rounds with Price Feedback in auction experiment Valuation: An Adversarial Collaboration. American Journal of Agricultural Economics 94 (1), 97-115. https://doi.org/10.1093/ ajae/aar066.

Creusen, M.E.H., Gemser, \& G., Candi, M. (2018). The influence of experiential augmentation on product evaluation. European Journal of Marketing, 52, 925945. https://doi.org/10.1108/EJM-04-2016-0220. 
Di Vita, G., Pappalardo, G., Chinnici, G., La Via, G., D'Amico, N., 2019. Not everything has been still explored: Further thoughts on additional price for the organic wine. Journal of Cleaner Production520-528. https://doi.org/10.1016/j. jclepro.2019.05.268.

Galati, A., Crescimanno, M., Tinervia, S., Fagnani, F., 2017. Social media as a strategic marketing tool in the Sicilian wine industry: Evidence from Facebook. Wine Economics and Policy 6(1), 40-47, https://doi. org/10.1016/j.wep.2017.03.003.

Galati, A., Schifani, G., Crescimanno, M., Migliore, G., 2019a. "Natural wine" consumers and interest in label information: An analysis of willingness to pay in a new Italian wine market segment. Journal of Cleaner Production 227, 405-413, https://doi.org/10.1016/j. jclepro.2019.04.219.

Galati, A., Tinervia, S., Tulone, A., Crescimanno, M., 2019b. Drivers affecting the adoption and effectiveness of social media investments: The Italian wine industry case. International Journal of Wine Business Research 31(2), 260-278, https://doi.org/10.1108/ IJWBR-04-2018-0016.

Galloway, G., Mitchell, R., Getz, D., Crouch, G., Ong, B., 2008. Sensation seeking and the prediction of attitudes and behaviours of wine tourists. Tourism Management 29 (5), 950-966. https://doi.org/10.1016/j. tourman.2007.11.006.

Getz, D., Brown, G., 2006. Critical success factors for wine tourism regions: a demand analysis. Tourism Management 27 (1), 146-158. https://doi. org/10.1016/j.tourman.2004.08.002.

Goode, M.R., Dahl, D.W., Moreau, C.P., 2010. The Effect of Experiential Analogies on Consumer Perceptions and Attitudes. Journal of Marketing Research 47 (2), 274-286. Retrieved from http://www.jstor.org/stable/25674426.

Huffman, W.E., Shogren, J.F., Rousu, M., Tegene, A., 2003. Consumer Willingness to Pay for Genetically Modified Food Labels in a Market with Diverse Information: Evidence from Experimental Auctions. Journal of Agricultural and Resource Economics 28 (3), 481-502.

Iaia, L., Scorrano, P., Fait, M., Cavallo, F., 2017. Wine, family businesses and web: marketing strategies to compete effectively. British Food Journal 119(11), 2294-2308, https://doi.org/10.1108/BFJ-02-2017-0110.

Jang, S.S., Namkung, Y., 2009. Perceived quality, emotions, and behavioural intentions: application of an extended Mehrabian-Russell model to restaurants. Journal of Business Research 62 (4), 451-460. https:// doi.org/10.1016/j.jbusres.2008.01.038.
Kaplan, S. 1987. Aesthetics affect and cognition: Environmental preference from an evolutionary perspective. Environment and Behaviour 19 (1), 3-32. https://doi. org/10.1177/0013916587191001.

Kergoat, M., Giboreau, A., Nicod, H., Faye, P., Diaz, E., Beetschen, M.A., Gerritsen, N., Meyer, T., 2010. Psychographic measures and sensory consumer tests: When emotional experience and feeling-based judgments account for preferences. Food Quality and Preference 21 (2), 178-187. https://doi.org/10.1016/j. foodqual.2009.06.006.

King, S.C., Meiselman, H.L., 2010. Development of a method to measure consumer emotions associated with foods. Food Quality and Preference 21 (2), 168177. https://doi.org/10.1016/j.foodqual.2009.02.005.

Kotler, P., 1973. Atmospherics as a marketing tool. Journal of Retailing 49 (4), 48-64.

Lange, C., Martin, C., Chabanet, C., Combris, P., Issanchou, S., 2002. Impact of the information provided to consumers on their willingness to pay for Champagne: comparison with hedonic scores. Food Quality and Preference 13, 597-608. https://doi. org/10.1016/S0950-3293(02)00059-9.

List, J.A., 2003. Using random nth price auctions to value non-market goods and services. Journal of Regulatory Economics 23 (2), 193-205. https://doi. org/10.1023/A:1022259014448.

Lusk, J.L., Shogren, J. 2007. Experimental Auctions: Methods and Applications in Economic and Marketing Research. Cambridge UK, Cambridge University Press. https://doi.org/10.1017/CBO9780511611261

Mehrabian, A., Russell, J.A., 1974. An Approach to Environmental Psychology. MIT Press, Cambridge.

Menini, A., 2017. Experience management practices and wineries' economic performance the Italian case. Conference paper, 11th Annual AAWE Conference 2017 in Padua, Italy (June 28 - July 2, 2017).

Muruganantham, G., Bhakat, R.S., 2013. A review of impulse buying behaviour. International Journal of Marketing Studies 5(3), 149-160. http://dx.doi. org/10.5539/ijms.v5n3p149.

Orth, U.R., Bourrain, A., 2005. Ambient scent and consumer exploratory behaviour: a causal analysis. Journal of Wine Research 16 (2), 137-150. https://doi. org/10.1080/09571260500327671.

Pappalardo, G., Lusk, J.L., 2016. The role of beliefs in purchasing process of functional foods. Food Quality and Preference 53, 151-158. https://doi.org/10.1016/j. foodqual.2016.06.009.

Pappalardo. G., Chinnici, G., Pecorino, B., 2017. Assessing the economic feasibility of high heat treatment, using evidence obtained from pasta facto- 
ries in Sicily (Italy). Journal of Cleaner Production 142 (Part 4), 2435-2445. https://doi.org/10.1016/j. jclepro.2016.11.032.

Pappalardo, G., Selvaggi, R., Bracco, S., Chinnici, G., Pecorino, B., 2018. Factors affecting purchasing process of digestate: evidence from an economic experiment on Sicilian farmers' willingness to pay. Agricultural and Food Economics, 6:16, 1-12. https://doi. org/10.1186/s40100-018-0111-7.

Pine, B.J., Gilmore, J., 1999. The Experience Economy: Work is Theatre and Every Business a Stage. Cambridge, MA, Harvard Business School Press.

Platania, M., Platania, S., Santisi, G., 2016a. Entertainment marketing, experiential consumption and consumer behaviour: the determinant of choice of wine in the store. Wine Economics and Policy 5 (2), 87-95. https://doi.org/10.1016/j.wep.2016.10.001.

Platania, M., Rapisarda, P., Rizzo, M., 2016b. Wine tourism: website quality of wine roads in Italy. Quality Access to Success 17, 242-250.

Pomarici, E., Lerro, M., Chrysochou, P., Vecchio, R., Krystallis, A, 2017. One size does (obviously not) fit all: Using product attributes for wine market segmentation. Wine Economics and Policy 6 (2), 98-106. https://doi.org/10.1016/j.wep.2017.09.001.

Prescott, J., 2017. Some considerations in the measurement of emotions in sensory and consumer research. Food Quality and Preference 62, 360-368. https://doi. org/10.1016/j.foodqual.2017.04.005.

Purcell, A.T., Peron, E., Berto, R., 2001. Why do preferences differ between scene types? Environment and Behavior 33 (1), 93-106. https://doi. org/10.1177/00139160121972882.

Reimann, M., Zaichkowsky, J., Neuhaus, C., Bender, T., Weber, B., 2010. Aesthetic package design: a behavioral, neural, and psychological investigation. Journal of Consumer Psychology 20, 431-441. https://doi. org/10.1016/j.jcps.2010.06.009.

Richins, M.L., 1997. Measuring Emotions in the Consumption Experience. Journal of Consumer Research 24 (2), 127-146. https://doi.org/10.1086/209499.

Ruiz, C., Hernández, B., 2014. Emotions and coping strategies during an episode of volcanic activity and their relations to place attachment. Journal of Environmental Psychology 38, 279-287. https://doi. org/10.1016/j.jenvp.2014.03.008.

Santini, C., Cavicchi, A., Canavari, M., 2011. The Risk (TM) strategic game of rural tourism: how sensory analysis can help in achieving a sustainable competitive advantage, in Sidali, K.L., Spiller, A., Schulze, B. (Eds.), Food, Agri-Culture and Tourism, Springer, Berlin, pag. 161-179.
Santini, C., Cavicchi, A., Casini, L., 2013. Sustainability in the wine industry: key questions and research trends. Agricultural and Food Economics 1:19, 1-14. https:// doi.org/10.1186/2193-7532-1-9.

Schimmenti, E., Migliore, G., Di Franco, C.P., Borsellino, V. 2016. Is there sustainable entrepreneurship in the wine industry? Exploring Sicilian wineries participating in the SOStain program. Wine Economics and Policy 5(1), 14-23, https://doi.org/10.1016/j. wep.2016.05.001.

Schmitt, B., 2010. Experience Marketing: Concepts, Frameworks and Consumer Insights. Foundations and Trends in Marketing 5 (2), 55-112. http://dx.doi. org/10.1561/1700000027.

Selvaggi, R., Chinnici, G., Pappalardo, G., 2018a. Estimating willingness to pay for digestate: evidence from an economic experiment from Sicilian farmers. Quality - Access to Success 19 (S1), 489-493.

Selvaggi, R., Verduci, M., Pecorino, B., 2018b. Estimate of willingness to pay for Etna red wines: evaluation of the existence of an experiential component in purchase phase. Quality - Access to Success 19 (S1), 494-499.

Shogren, J.F., Margolis, M., Koo, C., List, J.A., 2001. A random nth-price auction. Journal of Economic Behavior \& Organization 46 (4), 409-421. https://doi. org/10.1016/S0167-2681(01)00165-2,

Spinelli, S., 2017. Implications of the science of emotion for applied research: Comments on Prescott (2017). Food Quality and Preference 62, 369-371. https://doi. org/10.1016/j.foodqual.2017.05.013.

Sturiale, L., Scuderi, A., 2017. Interaction between the Emotional and Rational Aspects in Consumer Buying Process for Typical Food Products of Italy, in: M.A. Do Santos (Ed.), Applying Neuroscience to Business Practice, (Chapter 7, 142-162), IGI Global.

Teng, C.I., Tseng, H.M., Wu, H.H., 2007. Positive mood as a mediator of the relations among musical preference, post-consumption product evaluation, and consumer satisfaction. Psychological Reports 100, 927938. https://doi.org/10.2466/pr0.100.3.927-938.

Vecchio, R., 2013. Determinants of willingness-to-pay for sustainable wine: Evidence from experimental auctions. Wine Economics and Policy 2, 85-92. https:// doi.org/10.1016/j.wep.2013.11.002.

Voss, C., Roth, A.V., Chase, R.B., 2008. Experience, service operations strategy, and services as destinations: foundations and exploratory investigation. Production and Operations Management 17, 247-266. https://doi.org/10.3401/poms.1080.0030.

Wongprawmas, R., Pappalardo, G., Canavari, M., Pecorino, B., 2016. Willingness-to-Pay for Multiple Units of 
Eco-Friendly Wheat-Derived Products: Results from Open-Ended Choice Experiments. Journal of Food Products Marketing 22 (6), 658-682. https://doi.org/1 $0.1080 / 10454446.2015 .1121438$.

Yuan, J., Cai, L., Morisson, A., Linton, S., 2005. An analysis of wine festival attendees' motivations: a synergy of wine, travel and special events?. Journal of Vacation Marketing 11 (1), 41-58. https://doi. org/10.1177/1356766705050842.

Zube, E.H., Pitt, D., Anderson, T.W., 1975. Perception and prediction of scenic resource values of the Northeast, in Zube, E.H., Brush, R.O., Fabos J.G. (Eds.), Landscape assessment: Values, perceptions and resources, Stroudsburg, PA, Dowden, Hutchinson and Ross, pp. 151-167. 